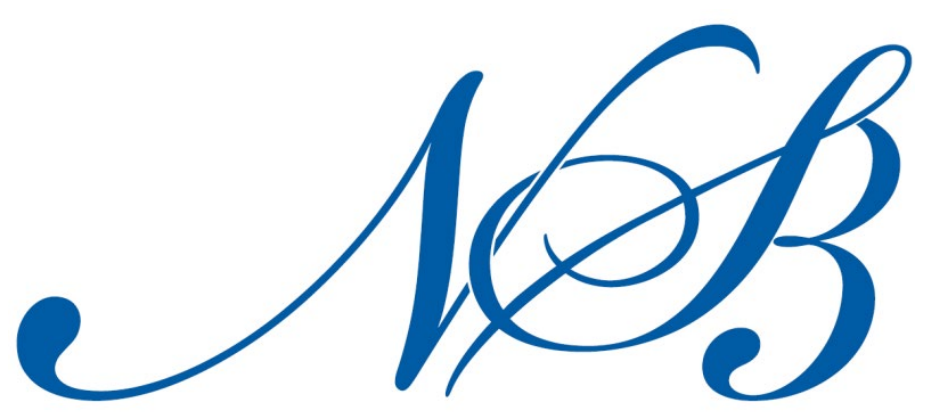

NOTULAE SCIENTIA

\title{
BIOLOGICAE
}

\section{Volume 12, Issue 4}

\section{Published by AcademicPres on behalf of: \\ Horticulture and Forestry Society from Transylvania}

\section{Abstracted and/or indexed:}

- Directory of Open Access Journals

- Elton B Stephens COmpany (EBSCO) (Academic Search Complete; AS Premier; AS Elite; AS Alumni Edition; AS Ultimate)

- ProQuest (ProQuest Central; Biological Science Database; Agriculture Science Database; East Europe, Central Europe Database; Publicly Available Content Database)

- Centre for Agriculture and Biosciences International (CABI) (Plant Sciences - subject; CAB Abstracts)

- Chemical Abstracts Service (CAS)

- Ulrich's Periodicals Directory

- Russian Scientific and Technical Information Institute (VINITI)

- $\quad$ Bielefeld Academic Search Engine (BASE)

- British Library Direct (BLD)

- The European Library

- Genamics JournalSeek

- OCLC WorldCat

- Harvard Library

- CrossRef

- UGC Approved List of Journal - India (important to authors from India)

- Information Matrix for the Analysis of Journals (MIAR) $(\mathrm{ICDS}=\underline{6.0}$ )

- Google Scholar (Google Scholar Metrics $\underline{\text { h5 }=11}$ )

- Scilit (Journal Ranking in 2019: 1105/49685) 


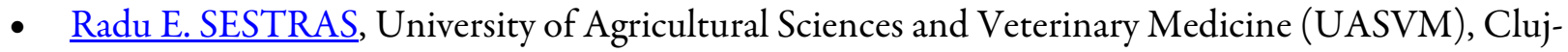
Napoca, Romania

- Sorana D. BOLBOACĂ, University of Medicine and Pharmacy, Cluj-Napoca, Romania

- Oscar VICENTE, COMAV, Universitat Politècnica de València, Valencia, Spain

\section{Advisory Editors}

- Cornel CĂTOI, UASVM Cluj-Napoca, Romania (Rector, UASVM)

- Doru C. PAMFIL, UASVM Cluj-Napoca, Romania (President, Cluj-Napoca Branch of Romanian Academy)

- Viorel MITRE, UASVM Cluj-Napoca, Romania (President, SHST)

- Monica BOSCAIU, Polytechnic University of Valencia, Spain

- Birsen ÇAKIR, Ege University, Izmir, Turkey

- Milić ČUROVIĆ, Montenegro Univ., Podgorica, Montenegro

- Hossam S. EL-BELTAGI, Cairo University, Cairo, Egypt; King Faisal University, Al-Ahsa, Saudi Arabia

- Lorentz JÄNTSCHI, Polytechnic University of Cluj-Napoca, Romania

- Kamil KUČA, University of Hradec Králové, Hradec Králové, Czech Republic

- Leonardo LEONARDI, University of Perugia, Italy

- Allan Klynger Da Silva LOBATO, Universidade Federal Rural da Amazônia, Paragominas, Brazil

- Felicia LOGHIN, University of Medicine and Pharmacy, Cluj-Napoca, Romania

- Andrei Daniel MIHALCA, UASVM Cluj-Napoca, Romania

- Andrei MOCAN, University of Medicine and Pharmacy, Cluj-Napoca, Romania

- Losé Alberto PEREIRA, Instit. Politécnico de Bragança, Portugal

- Ioana Delia POP, UASVM Cluj-Napoca, Romania

- Agnieszka SEKARA, Agricultural University of Kraków, Kraków, Poland

- Adriana F. SESTRAȘ, UASVM Cluj-Napoca, Romania

- Lei SHI, Huazhong Agricultural University, Wuhan, China

- Pilar S. TESTILLANO, Biological Research Centre, Madrid, Spain

- Robert VEBERIČ, University of Ljubljana, Ljubljana, Slovenia

- Dan VODNAR, UASVM Cluj-Napoca, Romania 
- $\quad$ Anthony Jide AFOLAYAN, University of Fort Hare, Alice Campus, South Africa

- Ioan Vasile ABRUDAN, Transilvania University, Braşov, Romania

- Douglas D. ARCHBOLD, University of Kentucky, Lexington, USA

- Grigore BĂCIUT, University of Medicine and Pharmacy, Cluj-Napoca, Romania

- Umberto BERNABUCCI, University of Tuscia, Viterbo, Italy

- Dimitrios BILALIS, Agricultural University of Athens, Athens, Greece

- Anca Dana BUZOIANU, University of Medicine and Pharmacy, Cluj-Napoca, Romania

- Suriyan CHA-UM, National Center for Genetic Engineering and Biotechnology (BIOTEC), Thailand

- Ioan COMAN, University of Medicine and Pharmacy, Cluj-Napoca, Romania

- Vasile CRISTEA, Babes-Bolyai University, Cluj-Napoca, Romania

- $\quad$ Róbert FARKAS, Szent István University, Budapest, Hungary

- $\quad$ Ana FITA, Polytechnic University of Valencia, Spain

- László FODOR, Szent István University, Budapest, Hungary

- Francisco FUENTES, Pontifical Catholic University of Chile, Chile

- Marek GAJEWSKI, Warsaw Agricultural University, Warsaw, Poland

- Stefano GREGO, University of Tuscia, Viterbo, Italy

- Hulya ILBI, Ege University, Izmir, Turkey

- Florin IORAȘ, Buckinghamshire New University, High Wycombe, United Kingdom

- Alexandru IRIMIE, 'Ion Chiricuta' Cancer Institute, Cluj-Napoca, Romania

- Stefania MASCI, University of Tuscia, Viterbo, Italy

- Dan MIHU, University of Medicine and Pharmacy, Cluj-Napoca, Romania

- Meena MISRA, Institute of Frontier Sciences and Biotechnology, Baramunda, Bhubaneswar, India

- Bernardo MURILLO-AMADOR, Centro de Investigaciones Biologicas del Noroeste, La Paz, Mexico

- Vladimir PEŠIĆ, University of Montenegro, Podgorica, Montenegro

- Neiva Izabel PIEROZZI, Instituto Agronômico de Campinas, CPDR Geneticos Vegetais, Brazil

- Jaime PROHENS, Polytechnic University of Valencia, Valencia, Spain

- $\quad$ Chen QIN, School of Life Science, Shanghai Univ., Shanghai, China

- Adrián RODRÍGUEZ-BURRUEZO, Polytechnic University of Valencia, Valencia, Spain

- Marco SARIGU, Università degli Studi di Cagliari, Cagliari, Italy

- Klaus SCHALLER, Research Center Geisenheim, Geisenheim, Germany

- Anoop Kumar SRIVASTAVA, ICAR - Central Citrus Research Institute, Nagpur, India

- Franci STAMPAR, University of Ljubljana, Ljubljana, Slovenia

- $\quad$ Feng XU, Yangtze University, Jingzhou 434025, Hubei Province, China 
- $\quad$ Adriana D. BACIU, UASVM Cluj-Napoca, Romania

- Cătălina DAN, UASVM Cluj-Napoca, Romania

- Mihail KANTOR, Mycology and Nematology Genetic Diversity and Biology Laboratory USDA, ARS, Beltsville, MD 20705, USA

- Laura Ioana MACAVEI, Università degli Studi di Modena e Reggio Emilia, Modena, Italy

- $\quad$ Lucica MIHALTE, UASVM Cluj-Napoca, Romania

- Corina F. SERBAN, Washington State University, Stone Fruit Breeding \& Genetics, IAREC, Prosser, WA 99350-8694, USA

- $\quad$ Alina M. TRUȚĂ, UASVM Cluj-Napoca, Romania

\section{Linguistic Editors}

- Mihaela RUSU, UASVM Cluj-Napoca, Romania

- Rodica STAN, UASVM Cluj-Napoca, Romania

\section{Journal Office}

- Roxana L. STOIAN, UASVM Cluj-Napoca, Romania

- Silviu L. MIC, UASVM Cluj-Napoca, Romania

\section{Technical Support}

- Diana-Maria MIRCEA, UASVM Cluj-Napoca, Romania

- Andreea D. ONA, UASVM Cluj-Napoca, Romania

- Ioana Maria PLEȘA, UASVM Cluj-Napoca, Romania

- Diana Alexandra POP, UASVM Cluj-Napoca, Romania

- Paula STAN (GAVRIS), UASVM Cluj-Napoca, Romania

- Irina M. TODEA (MORAR), UASVM Cluj-Napoca, Romania

\section{Notice}

To be cited Notulae Scientia Biologicae or abbreviated title Not Sci Biol.

The Editorial Board of Not Sci Biol is not responsible for statements and opinions published; they represent the views of the authors or persons to whom they are credited. Publication of research information does not constitute a recommendation or endorsement of products involved. 


\section{Aims and scope}

Notulae Scientia Biologicae is a quarterly peer-reviewed journal aimed at disseminating significant research and original papers, critical reviews and short reviews on life sciences and medicine, development of new methodologies that can be of interest to a wide audience of scientists in all areas of biology sciences. The journal encourages authors to frame their research questions and discuss their results in terms of the major questions of biology, agriculture, horticulture, forestry, biotechnology and medicine, thereby maximizing the impact, spreading and value of their research. The papers must be of potential interest to a significant number of scientists and, if specific to a local situation, must be relevant to a wide body of knowledge in life and medical sciences. Articles should make a significant contribution to the advancement of knowledge or toward a better understanding of existing biological, agricultural and medical concepts. An international Editorial Board advises the journal. The total content of the journal may be used for educational, non-profit purposes without regard to copyright. The distribution of the material is encouraged with the condition that the authors and the source (Notulae Scientia Biologicae or Not Sci Biol) are mentioned.

\section{Submission}

The journal offers to authors a fully web-enabled online manuscript submission, instructions for authors and review system available at http://www.notulaebiologicae.ro

Papers are published in English (British spelling) and the authors are fully responsible for the originality of their papers and for the correctness of their subject-matter, language and formal attributes. Authors whose mother tongue is not English are strongly urged to have their manuscripts reviewed linguistically before submission.

Manuscripts submitted must be edited, for clarity and conformity purposes according to Authors guidelines, and must not have been previously published or simultaneously submitted elsewhere.

The papers can be submitted online by the "senior author" (the main author, or the person who takes responsibility for the integrity of the work as a whole, from submission to the published article). The submission process is described on the web site.

An Author Statement, available on the website, should be enclosed by "senior author" declaring that the paper has not been published anywhere else, permission to reproduce the material, authorship credit, contributors and creditors for the integrity of the work as a whole, to avoid the conflicts of interest and scientist fraud, and respecting the ethical principles of publishing, research and scientific rights.

\section{Publication Frequency}

Quarterly (four issues per volume/year):

Issue 1: January-March

Issue 2: April-June

Issue 3: July-September

Issue 4: October-December

\section{Publication Ethics and Publication Malpractice Policy}

The journal respects the publication ethics norms, based on internationally accepted best practice guidelines for journal editors, notably the Committee on Publication Ethics (COPE), the World Association of Medical Editors Ethics (WAME), the International Committee of Medical Journal Editors (ICMJE) and Consolidated Standards of Reporting Trials (Consort). 


\section{Editorial}

Introduction pages

\section{Research articles}

The influence of human chorionic gonadotropin on hormonal and haematological profile of

Martins S. AKOGWU, Chukwuka N. UCHENDU, Rita I. ODO

Phylogenetic observation in Ariidae, Bagridae and Plotosidae catfishes by COI gene sequence analysis Thathiredypalli R. BARATHKUMAR, Muthusamy THANGARAJ

A preliminary study and new distributional records of family Erebidae (Leach, [1815]) (Lepidoptera: Noctuoidea) from Aligarh, Uttar Pradesh, India

Shahabab A. FAROOQUI, Hina PARWEZ, Rahul JOSHI

Evaluation of pearl millet (Pennisetum glaucum L. (R. Br.)) landraces for resistance to stem borer (Coniesta ignefusalis Hampson.) infestation Abdulhakeem ABUBAKAR, Olamide A. FALUSI, Israel K. OLAYEMI, Matthew O. ADEBOLA, Yusuf O. A. DAUDU, Mohammed C. DANGANA

New varieties of tomato - morphological aspects and molecular characterisation with RAPD and SSR markers

Adriana BĂDULESCU, Carmen F. POPESCU, Anamaria M. DUMITRU, Dorin I. SUMEDREA

Photochemical responses of cucumber (Cucumis sativus L.) plants to heat stress

$829-835$

Ali DOĞRU

Vegetative propagation of cornelian cherry (Cornus mas L.) selections

Felicia CORNESCU, Gheorghe ACHIM, Sina COSMULESCU

Effect of pre-storage hot air and hot water treatments on post-harvest quality of mango (Mangifera indica Linn.) fruit Oluwole O. OLADELE, Olajide I. FATUKASI

Structure and histochemistry of sorghum caryopsis in relation to grain-filling

Pollen grain expression of osmotic adjustment as a screening method on drought tolerance in several wine and table grape genotypes (Vitis vinifera L.)

BĂNUȚĂ

Ameliorative roles of compost on okra (Abelmoschus esculentus L.) exposed to drought stress at 
Effect of snowmelt regime on phenology of herbaceous species at and around treeline in Western

Bhupendra S. ADHIKARI; Rahul KUMAR

Bioremediation of diesel polluted soils with Eichhornia crassipes (water hyacinth)

920-928

Saheed I. MUSA, Felix M. OKE, Charlotte C. NDIRIBE

Lignin, cellulose and nutrient deposition in litters of Bambusa vulgaris stands in a regenerating forest

929-939

Tolulope V. BORISADE

Trees, seeds and seedlings analyses in the process of obtaining a quality planting material for black locust

940-958

(Robinia pseudoacacia L.)

Andrea M. ROMAN, Irina M. MORAR, Alina M. TRUT,A, Cătălina DAN, Adriana F. SESTRAȘ, Liviu

HOLONEC, Florin IORAS, Radu E. SESTRAS

Geospatial analysis-based approach for assessing urban forests under the influence of different human

Oluwayemisi S. OLOKEOGUN, Abiodun O. OLADOYE, Oluwatoyin O. AKINTOLA 
Mailing Address

Notulae Scientia Biologicae

Radu E. SESTRAS, Editor-in-Chief

University of Agricultural Sciences and Veterinary Medicine

3-5 Manastur St., 400372 Cluj-Napoca, Romania

Phone: +40 264-596 384; Fax: +40 364-819 182

Email: rsestras@notulaebiologicae.ro

\section{Technical Support Contact}

Email: editor1@notulaebiologicae.ro

\section{Journal Sponsorship}

\section{Publisher}

- Horticulture and Forestry Society from Transylvania by AcademicPres

\section{Sponsors}

- Horticulture and Forestry Society from Transylvania

- University of Agricultural Sciences and Veterinary Medicine (UASVM)

- Romanian Academy of Agricultural and Forestry Sciences

\section{Sources of Support}

Additional agencies or organizations that provide financial or in-kind support: SC TOPOCAD
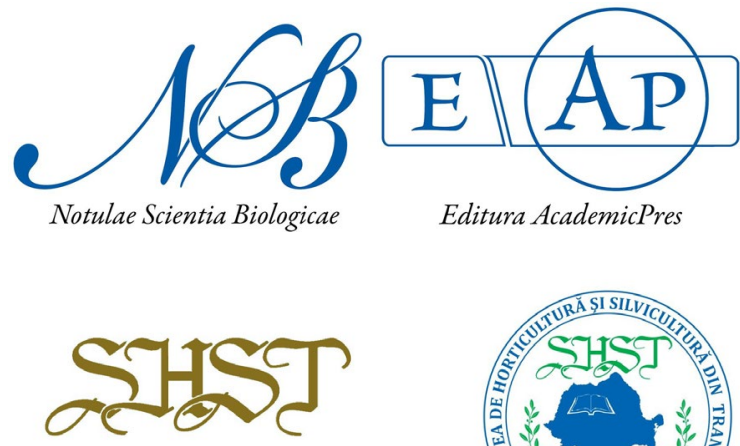

HORTICULTURE AND FORESTRY SOCIETY FROM TRANSYLVANIA
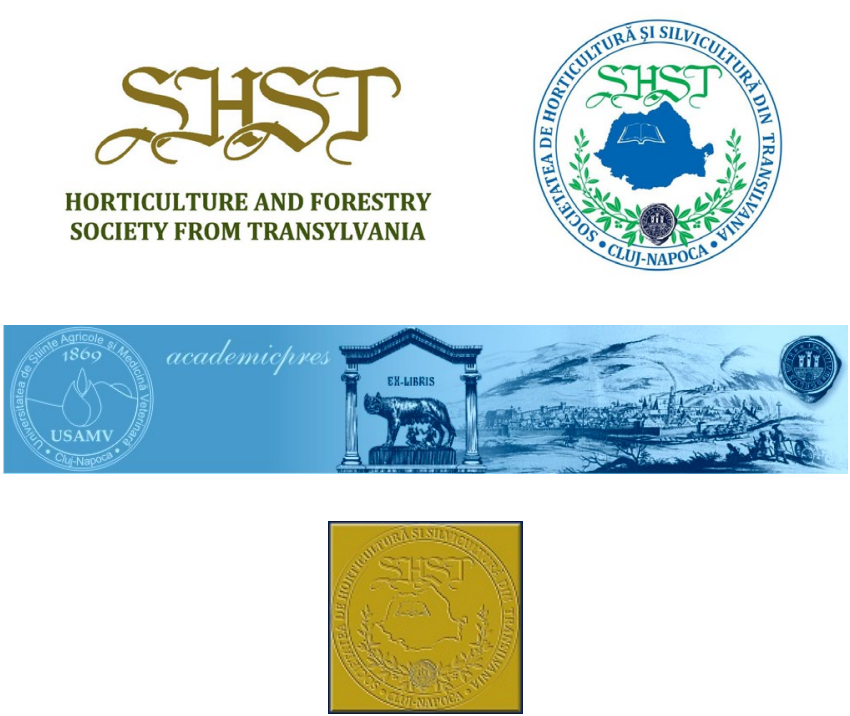